\title{
HUNTINGTON AND THE LIBERAL THOUGHT. PROBLEMS OF ANGLO-DEMOCRACY TO UNDERSTAND POLITICS
}

\author{
Maximilano Korstanje \\ International Society for Philosophers, Sheffield (United Kingdom) \\ Universidad de Palermo, Argentina
}

http://dx.doi.org/10.5209/rev_NOMA.2013.v37.n1.42560

\begin{abstract}
The liberal thought has inspired philosophy and sociology during years. From its view, US has two main goals. One is to expand the civilized culture to other non-western countries, and second to grant the democratic values. Paradoxically, terrorism poses one of the most troubling aspects of contemporanean democracy. On one hand, not only it defies the democratic resources to anticipate the next blow, but also put US to conduct one-sided attacks to autonomous countries. To legitimize the expansion of this new imperial order, the liberal discourse appealed to two strategies: first and foremost, denoting pejoratively as the case of Latin America that there is a cultural matrix that impedes these countries to embrace democracy. Secondly, it evidences the own myopia and ignorance to understand terrorism and politics. Our thesis is that US and England practiced a distortion of Democracy to colonize the world, the Anglo-democracy. As a social construe, democracy was conducive to the protection of status quo's interests
\end{abstract}

Keywords.- Liberal Thoughts, Huntington, Anglo democracy, Terrorism

\section{Introduction}

To what extent globalization has exerted influence to the rise of conflict and terrorism still remains a topic which is being discussed in the academic circles. In one direction, the globalization accelerates trade to create an unfettered market. This of course brings some benefits to all industrial countries, but has a cost. On another direction, the globalized-connected economies encourage the social conflicts and resentment in the world. At time, the market are being liberalized, walls are built to prevent the migration (Powell, 2010). The concept of development seems to be conducive to terrorism. D. Altheide, one of the most important scholars who studied terrorism, adds that the media makes from terrorism an excuse to victimize before the ever-changing citizen's protest. State not only manipulates the situation to impose policies which otherwise would be rejected, but also appeals to construct an ethnocentric view of otherness (Altheide, 2009). 
As this explanation given, $11 / 9$ re-signified the way people see terrorism, as well as triggered a particular fear to Muslims. Even, scholarship failed to articulate a coherent discourse respecting to the effects and reason of this traumatic event. Some scholars incline to think government should intervene in other countries that give protection to terrorists (Fukuyama, 1989) (Huntington, 1993; 1997) (Kristol and Kagan, 1996) (Vargas-Llosa, 2002) (Rashid, 2002) (Kepel, 2002) (Keohane and Zeckhauser, 2003) (Susstein, 2005) (Pojman, 2006) (Diamond, 2010), while others warn on the danger that represents for the democracy the fact of violating the autonomy of other countries (Somnez, 1998) (Altheide, 2006; 2009) (Said, 2001) (Sontag, 2002) (Holloway and Pelaez, 2002) (Zizek, 2009) (Skoll, 2007) (Bernstein, 2006) (Baudrillard, 1995a; 1995b; 2006) (Smaw, 2008) (Pech and Slade, 2006) (Corey, 2009) (Wolin, 2010).

Left-wind intelligentsia focuses on the conceptual problems of capitalism to respect the diversity. Besides, there are some incongruencies in the way government and media portrayed the Islam. Starting from the premise, globalization enhances the intercultural connection, political fear, events like 9/11 awakes up, contribute to enhance the loyalty for the state. What these intellectuals see is that the protests of worker unions, for example, are undermined whenever the nation is under attack. The interests of elite for keeping the psychological boundaries with others, seems to be conducive to global corporations which take presence in middle east at the time in their respective homes Muslims are traced and screened.

L. Howie argues convincingly that terrorism may pose a serious challenge to the democratic life because it is undermining not only the trust in institutions, but also allowing to government to intervene in the rights of people. The phantom of terrorism is mythically portrayed as a hazard to the democracy, but what rightled scholars did not see is that the psychological fear is eroding the basis of democracies. The fright to be attacked in a near future leads citizens to ad-hoc diagnosis prepared by pseudo-experts who are interested in protecting some interests. (Howie, 2009). Theoretical appliances of preventive war are selfdefeating for US and Europe because not only it posed their economies in a difficult position but also weakens the bridge of a frank dialogue. Totalitarian Regimes historically opted for preventive wars in order for them to gain more power and legitimacy (Gray, 2007). Therefore, the present paper explores not only the problems of terrorism but also situates two senior philosophers, Slavoj Zizek and Samuel Huntington to expand the current understanding of the dangers terrorism represents for democracy.

\section{Considering Religion as the cause of inter-civilization's conflict}

Samuel P. Huntington is a political scientist who has widely contributed in the fields of terrorism. His legacy gives light to many scholars, and for that we think he deserves some credits. In the following line, anyway, we strongly believe his argument should be placed under the lens of scrutiny, his ethnocentric viewpoint, or the mis-diagnosis that alerted to a clash of civilizations. 
Huntington considers that the class-struggle will set the pace to a new types of conflicts, more bloody based on the encounter between diverse cultures. These cultures not only represent contrasting values, but also are opposed by the imposition of violence:

"In this new world the most pervasive, important and dangerous conflicts will not be between social classes, rich and poor, or other economically defined groups, but between people belonging to different cultural identities. Tribal wards and ethnic conflicts will occur within civilizations. Violence between states and groups from different civilizations, however, carries with it the potential for escalation as other states and groups from these civilizations rally to the support of their kin countries" (Huntington, 1997: 28).

This prerogative on what means the identity assumes that violence plays a pivotal role in the configuration of nationhood. The decomposition of nationstate, rather, is creating a paradoxical situation. Pre and post cold war, cultural identities built the social fabric so that states can achieve the cohesion necessary to work. The clash of civilization would be irreversible. If yesterday, the violence were exerted on the bodies, now it has been re-directed to create a clash of civilizations. Huntington explains that this conflict surfaces because of natural incompatibilities between cultures.

Certainly, after the end of Soviet Union, world has been fragmented in 7 parts which are civilization: Latin American, African, Islamic, Sinic, Hindu, Orthodox, Buddhist, and Japanese and of course West shaped by USA, Australia and Western Europe. The success of democracy as a primary value depends on the development of society. In some areas as Middle East, where the tradition rules, democracy is impossible to flourish. This circumscribes to some countries to be prone to totalitarian or authoritarian regimes. Of course, these civilizations alternate integration and disintegration forces. At some extent, Muslims do not accept democracy as main form of government because of their religious values. Somehow, Islam deters democratic life. His faith, as Fukuyama, is posed to the end of history which represents the end of violence, when democracies maturate. The liberal democracy has won in the world because the red-wall collapsed.

Huntington is convinced the concept of civilization may be defined as a collective group, embedded into the history:

"The idea of civilization was developed by eighteen-century French thinkers as the opposite of the concept of barbarism . Civilized society differed from primitive society because it was settled, urban and literate. To be civilized was good, to be uncivilized was bad. The concept of civilization provided a standard by which to judge societies, and during the nineteenth century, Europeans devoted much intellectual, diplomatic and political energy to elaborating the criteria by which non-European societies might be judged sufficiently civilized to be accepted as members of European-dominated international system" (ibid: 41). 
Civilizations in plural can be expressed as units of cultural identity. Each culture would join forming structural units, looking for being more competitive in the administration of resources. The advance of technology or the importance to rules connotes significant aspect to define the boundaries of a civilization. It is not clear here is a civilization can be equaled in what anthropologist call a culture. He gives no traces on that. Rather, he prefers to say that "both (civilization and culture) offers similarly-minded functions. Culture provides the conceptual framework to understand the surrounding events, to solve the obstacles that threaten the group.

Although, civilization exhibits an attempt to link the self with its territory it represents a real expression of human creativity. The old concept of race not only is abandoned, but also countries may re-construct a valid reason to associate with others. The concept of civilization from its onset leads to division and association. More compatible cultures would coordinate efforts to fight against other less compatible. As Huntington put it, civilization solves the problems of ethnic affiliations. Ethnicity works only in limited spaces. Whenever globalization connects people, they tend to merge their traditions on others folks. The gravity of global world, in his viewpoint, paves the ways for the advent of conflict. One of the most troubling aspects in Huntington's account, is the lack of exhaustivity to define what a civilization is.

"Latin America, however, has a distinct identity which differentiates it from the West. Although an offspring of European Civilization, Latin America has evolved along every different path from Europe and North America. It has had a corporatist, authoritarian culture, which Europe had to a much lesser degree and North America at all" (ibid, 46).

The definition on Latin-American civilization obscures the own class of civilization theory. First and foremost, it is very hard to confirm that a culture may be authoritarian or democratic only in basis of history. Even, US supported the racial segregation during long time. The concept of democracy as the best government of the world as well as the application of individual liberties seems to be troublesome. It is incorrect to consider that democracy is based on how the authority is applied. Secondly, it is not clear to what an extent Latin American countries can be noted as non-democratic. If conflict and violence define what is a civilization, why does Huntington think violence (riots) is an expression of non-democratic life?. Furthermore, he looses the sight of history of democracy which shows how this regime may be as totalitarian as others. If U.S. is considered a democratic society, as Huntington wants, only because the economy has been liberalized, it does not respond to the years of slavery and minority-led segregation.

It is important not to loose the sight during 1970s and 80s many countries has democratized in the world wherein predominated the roots of Christianity. This was the case of a whole part of Latin America, Spain, Portugal Central and Southern of Europe with a strong basis of Catholicism. The process of democratization played a crucial role in the development of involved countries. This point reflects a previous interconnection between democracy and 
totalitarianism with religion. One might not being shocked when come across with excerpt like this:

"Democratization was most successful in countries where Christian influences were strong. New Democratic regimes appeared most likely to stabilize in the Southern and Central European countries that were predominantly Catholic or Protestant, and less certainly, in Latin American countries" (ibid: 193).

A provocative and polemic idea of this nature is developed in a second work entitled The third Wave wherein our sociologist of cabinet flourished all his Anglo-centrism. Democracy as we know today stems from a tradition coined in Greece. With this in mind, Huntington acknowledges that if democracy only functions as procedural elections this is a minimal definition. On another hand, it is really that

"Government produced by elections may be inefficient, corrupt, shortsighted, irresponsible, dominated by special interests, and incapable of adopting policies demanded by the public good. These qualities may make such government undesirable but they do not make them undemocratic. Democracy is one public virtue, not the only one, and the relation of democracy to other public virtues and vices can be only understood if democracy is clearly distinguished from other characteristics of political system" (Huntington, 1993: 10).

One of most important tenets of democracy seems to be the power (once again present in the argument of Huntington). Whether this is concentrated or not in few hands plays a pivotal role the meaning of democracy. It can be said that each democracy wave is reversed by a counter-force of totalitarianism. Europe and the World witnessed two tries of democratization corresponded with two reversed waves of fascisms. The scheme drew below most exemplify what we have mentioned.

First, Long wave of democratization

$1828 / 1926$

Firs reverse wave

1922-1942

Second, short wave of democratization

1943-1962

Second, reverse wave

1958-1975

Third wave of democratization

1974-

After further examination, Huntington sees how a cyclical process of peace and war operate in the core of democratized societies. Our cabinet Social scientist admires the political system of US to the extent to say that America should be contemplated as "the premier democratic country" because it is closely associated to freedom of individual rights.

By profiling a lot of theories aimed at explaining this issue, Huntington recognizes first and second wave of democratization corresponded with the following combined causes:

- A high overall level of economic wealth

- Actions of Market economy.

- $\quad$ Process of industrialization, urbanization and emergence of bourgeoisie. 
- $\quad$ Advent of Middle Class as a developed group

- $\quad$ Gradual decreasing of economic inequalities.

- $\quad$ And ultimately, traditions of respect of law and individual right inherited to Protestantism.

- $\quad$ Ally victory in First and Second War.

The case in Latin America seems to be a bit rare and different in comparison with the rest of world because democratization's process alternated cyclical patterns of back and forth between authoritarian (sectors accustomed to govern by coups) and democratic systems. It is important not to loose the sight of this following excerpt,

"these countries tended to oscillate between more populist democratic governments and more conservative military regimes. Under democratic regime radicalism, corruption, and disorder reach unacceptable levels and the military overthrow it, to considerable popular relief and acclaim. In due course, however, the coalition supporting the military regime, unravels, the military regime fails to deal effectively with the country's economic problems, professionally inclined military officers become alarmed at the politicization of the armed forces, and again, to great popular relief and acclaim, the military withdraw from and are pushed out of office" (ibid: 42).

Problems to explain the roots and evolution of democracy seem to be intertwined by a serious ignorance of the Hispanic culture. Huntington lacks of neither a coherent and scientific basis of his theses about Third World nor a definition of democracy. To understand better our critique on Huntington pseudo-thesis it is interesting to discuss the concept of democracies as it has been created in ancient Greece.

\section{Democracy and problems of Majorities}

By keeping with the role played by democracies in ancient World, C. Castoriadis, an specialist in these themes, argues that the Greek tradition is born after the advent of Homer Chronicles. From that day onwards, the social imaginary experienced a radical shift respecting essence of things and their depiction. The process of acculturation in Western culture received from Greece some values and surely discarded others. This type of selectivity remind us how Judaism leaves the Astronomy and Mathematics of their neighbor Babylonia and Syria while Romans are strongly interested in learning arts, philosophy and rights but there are no one who is concerned in Greek Geometry. The question as to why civilizations filter some values in detriment of others is unresolved in the development of Castoriadis. Rather, his thesis is that the spirit of Greece was founded on the significance of democracy and legislation. The honor for the law represents the essence of humanity.

On The Odyssey, whenever Ulysses visits the land of Cyclopes, Homer describes their habits and customs as monsters or appalling (with a large eye in the mid of head) without laws, or assemblies where issues can be debated by all members of community. Rules are often for Greek World this aspect that 
determines the boundaries between humanity and inhumanity. Monstrosity is often associated to another who does not share the same heritage with respect to politics organizations. Greece undoubtedly saw with certain admiration some barbarians who do not speak Greek but this was not a criterion of exclusion or fear; the term barbarian (barbaroi) was not necessarily pejorative. Of course, this was the case of Persia or Egypt. Both early mentioned countries had laws and a large tradition in legislation that perhaps captivated Greeks.

In the seminar of first day of December in 1982, Castoriadis argues that one of the respects that characterized tragedy is the presence of certainness in the future of hero. Unlike the drama wherein the suspense opens the doors of destiny taking in consideration that hero can avoid to his own death following the principle of contingency, the tragedy is circumscribed to a closed end that involved hero ignores but it is known for the rest of audience or readers. No matter the decision-making process, fate has been determined in the tragedy; things did not happen in other way than done. In a sharp contrast with Christianity which puts emphasis on the role played by god in predestination for humans, Greek mythology does understand that Gods are unable to change the destiny of humanity as well as their own one. Destiny transcends the will of god and human beings. Here, also, in other words, the lack contingency in tragedies is the reason why Aquiles or Oedipus cannot escape to their "moira" (a term linked to fortune we have already seen).

For Ancient Greek, the concept of moira means the immanency of death for all beings. Even, the gods (in their immortality) were not beyond the action of moira (fate). Destiny encompasses everything in homer tradition but mysteriously not the law. One of the characteristics that separate Greece from the rest of ancient mythical structures is the lack of revelation and prophecies about future. Since Greek mythology does not refer to a world created for humans, they comprehend that the body of laws is the only instruments capable to give order in politics fields. Even though, the predestination and divination were two widespread customs in order for solicitants to make business or face certain threats, nobody in Greece might have consulted these techniques to promulgate the laws. From this perspective, Castoriadis dwells on in those points that outline the main heritage of Ancient Greece. Among the contributions of this civilization we find the agonal competition for glory and fame, the quest of trust, the tension between essence and presence (doxa and nomos) and finally a determination for democracy. Here a point that merits a certain degree of consideration, ¿what is the relation between fate and competition?.

The criticism against the social imaginary is intertwined to indetermination of what never has certainly existed. Greek philosophy wakes up as a counter-act to the explanation of what we call the no-being (nothing). The abysm of what does not exist gains considerable force and acceptance for philosophers because of two reasons. The world created without a specific goal does not warranty to human beings the protection they need. For that it represents a hostile and awful place to be. The only way to face the threats coming from environment is the institution of a covenant between the community's members. Neither Plato nor Heidegger appreciates the exact essence of democracy and politics in their developments. As Y. Oikonomou put it, 
"in fact for Castoriadis politics is the conscious, critical and self-critical, rational, collective activity and inquiry, regarding the institution of society in whole or in part. In this sense, politics emerges when the question of the validity of the institution is posed, i.e., if and why the institutions are just: are the laws just?, is our Constitution just?, is it good. Good in relation to what? Constructed, which therefore presuppose the questioning of existing institutions - even if it means their acceptance in whole or in part" (Oikonomou, 2005: 6).

Following this argument, politics depends on the liability of people regarding to the public sphere. Social institutions facilitate the autonomy of citizenship before to the affairs they should daily face. Assembly constitutes the body where persons can debate and legislate about their problems, about the things which jeopardize their own style of life or their institutions (dangers).

The transference of power to representatives or politicians was not by the institution of popular vote. For that reason, Castoriadis realizes that the democracies do not give certainness about efficiency and efficacy in politics fields. Enrooted in the belief that democracy can assure a well-being for all members of assembly looks to be false, he reminds us otherwise this was a modern idea emerged after the distortion of Plato and stoicism about the Republic. Unlike Judaism which promises a better life in heaven, in Greek mythology there is nothing once dead that encourages an improvement for the bad conditions this world offer. Democracy as the government of fittest seems to be a concept only coined by Greeks, but how this concept worked, is pretty different than Huntington ideal world. As other scholars as Rawls, Huntington is centred in liberal view of democracy. What at the bottom he wants to say is that US is veiled to conquest other non-democratic countries because it expands the better of west civilization. Terrorism not only exhibits a counter-reaction to this expansion but a serious challenge for us. ¿Why Latin Americans are less democratic than Americans?, or ¿why we consider democracy a good value? are two of the many questions open the text of Huntington is unable to address.

\section{The Anglo-democracy}

Speaking of Anglo-democracy seems to be problematic. Many scholars, even in Latin America devoted considerable trust for democracy (Raventós, 2008; Murillo, 2008). Criticism against the inconsistencies of democracy has been highlighted by B. Susser (1992). The political structure of democracies creates bipolar forms of fanatics which lead to the dictatorships or populisms. The political systems are enrooted in cultural environments that not only precede the daily behavior but also the ways of making politics. Every society engenders a proper climate of politics which depending on the involving variables would develop totalitarian or democratic regimes. The problem with this point of view, R. Dahl adds, is that political scientists ignore the history of politics and how the human behavior has evolved in the passing of time. The desire of liberal American to see the republicanism in almost all non-western communities has been not only a prejudice but also a good instrument of colonization. That way, West has coined its right to decide what country is democratic and what should 
be expelled to embrace the democratic values (Dahl, 1992). D. Easton, a philosopher of politics, argues that politics as a science emerged as an obstacle, an impediment that circumscribes the citizen into ignorance. Since the lay people are not familiar with the ethic boundaries of politics, because they are far away from it, the study of political understanding is a way of controlling the performance of state (Easton, 1992). From its inception, Easton adds, the political science has debated to the dichotomy of democracy and efficiency. While the former grants the egalitarian access to justice for all, the latter legitimate the authority of governors. Almond \& Verba (1992) confirm that democracy and dictatorship has their differences. One of them seems to be the possibility to administrate the own decisions. Democracy looks to people to participate of public space whereas the totalitarianism evokes the submission to the stronger. Nonetheless, under some circumstances, a democracy may become in a dictatorship. Furthermore, C. Bay acknowledges that the politics surges from the diversity of views, which take the education as a form of socialization to achieve a good coordination. But at moments when the politics set the pace to pseudo-politics, which means that the personal power-will blurs the ethical boundaries of diversity, society erodes her democratic basis.

Based on his theory of justice, Ralws identifies five forms of political organizations. The concept of law-of people focuses on some questions linked to a utopia that confesses the desire almost all countries constitute in a democratic constitutional society. Starting from this premise, Rawls explains not only why some nations fail in this process but also the idea that motives the law of people in modern democracies. The first, he adds, is one of the evils of human history, unjust war and political oppression, the second refers to the social policies to eradicate deep-seated injustices. As the previous argument given, five subtypes of political organizations may be framed into Rawl's development:

a) reasonable law, b) descent people, c) outlaw-states, d) societies burdened by unfavorable conditions and e) benevolent absolutism.

The Theory of reasonable law rests on the belief that people sacrifice their appetite for war and ambitions if wider forms of political, economics, and social cooperation is achieved. Therefore, trade and negotiations are of paramount importance to balance the international relationships. Rawls sets forward a model to understand how the conflict may be undermined. The veil of ignorance not only facilitates an egalitarian dialogue among liberal peoples, but also determines the lack of self-determination. People behave without knowing their own possibilities or the settings were they move (Rawls, 1999). Similarly to Huntington, Rawls considers that people are free and independent by nature. Their bonds are part of a much broader covenant where the self-defense is based on the respect of rights. In this ideal world, Rawls, envisages that democratic countries appeals to peace to construct a durable state of cooperation among states (Rawls, 1999).

Political philosophy focused not only its effort in the problems of democracy to make from this world a better site to live, but also in the conceptual discrepancies respecting the ideological dangers of democracy poses for elites. 
One of the scholars who have made a substantial contribution in the study of democracy was Robert Castel. In his book, La metamorfosis de la cuestión social, Castel examines painstakingly the alterations suffered the social bond from Medieval Times to the modernity. The political freedom was conducive to the process of industrialization in late Medieval Times. The sense of liberty not only facilitated to internal migration directly to cities, but also situated farmers in a new unknown condition, the possibility of choice. As a result of this, many pour peasants were free to negotiate with more than one land-owner about their conditions of subsistence. The capital found the necessary mechanism, articulated by the doctrine of liberal-market and democracy to sustain the basis of nation-state. Whether the democracy in old Greece reminded the possibility of any citizen to derogate a law if necessary, the Anglo-democracy focuses on the voting process but creating a gap between citizens and their institutions. This hole is fulfilled by the financial powers that operate inside the nation-states. That way, the individual voices in democratic regimes were trivialized in view of the hegemony of jurisprudence and legal-theory. The laws sanctioned in modern parliamentary democracies seem not to be objected by citizens. The individual views fail against the corporate powers that monopolize the wellfunctioning of Republic. Therefore, it is contradictory to attack the market defending democracy. The capitalist logic today, enrooted in modern Anglodemocracy, are not being placed under the lens of scrutiny. The well functioning of Anglo-societies today depends on their efficiency to promote conflict in the periphery. The concept of Anglo democracy also represents the idea of republicanism, given not as a form of political commitment, but as a way of forging control over the institution of society. The order for England and US is based on the right of property as well as the degree of control elites has to dominate citizenry. The Anglo-democracy denotes a new type of organization, unknown until the British empires flourished. Although, electorate votes their authorities every four years, a point that makes to the republican order, they are impeded to derogate the laws sanctioned by the senate. This leads to modern society to corporative forms of democracy where the will of individuals are systematically violated. The liberal myopia in denouncing this depends on the prejudice that the safe republic is formed only when the rights of people granted. These rights are based not only the freedom to consume, but also in the property.

Anglo democracy is after all, a deformation consolidated by the end of WWII. The following table illustrates the characteristics of modern and old democracy.

Table 1 - Principles of Greek and Anglo Democracy

\begin{tabular}{|l|l|l|}
\hline Items of Analysis & Greek Democracy & Anglo Democracy \\
\hline Power & Derogation of laws & Voting \\
\hline Legitimacy & Partial & Total \\
\hline Citizenship & Few units & Global units \\
\hline Form of organization & The city and kinship & Corporations \\
\hline
\end{tabular}

Equally important, Greek democracy, as discussed, developed a limited application of power. Nor the authority of the kind would be defied, neither the figure of father. The Greek world was determined by the attachment to the city, a bondage which has been forged by the kinship. This means that democratic 
resource poses the citizen in egalitarian conditions to its senate but this has been applied to few units of people. Further, the citizen acquired a limited power respecting to the officials. Rather, the modern Anglo democracy not only liberalized the bondage to control over larger units of inhabitants, but also situated the Senate in opposition to the will of citizens. Although a law is considered unduly, people is unable to govern unless by means of their representants. The gap between the political institutions and people is obviously fulfilled by economic corporations which ultimately finance the future candidate to presidency. In these types of organizations the legitimacy seems to be totalized because there is no resource to change what is legalized by the senate. In sum, Anglo democracy takes from Republicanism; this means the division of power, its primary stronghold but subtly trivializes the necessary participation of individuals beyond the party apparatuses. In view of this, what makes US more democratic than Argentina?.

An excellent survey conducted by Haggard \& Kaufman showed how coups and democracies are inextricably intertwined. Examining more than 20 cases in Asia, Latin America and Africa, these specialists suggest that the democratic transitions and their passage to dictatorships depend on the way the legitimacy is managed. The failures in economic policies affect the degree of cohesion of the society. Since the political system is unable to correct the glitches, simply because elite keeps no the legitimacy enough to introduce adjustments, the instability is given as a reaction to abolish or perpetuate the status-quo. The thesis of Haggard \& Kaufman is that irrespective of culture or cultural values, the passage from a democracy to a dictatorship explains by the failures or success in regulating the economic factor of production. To this end, democracy or dictatorships are forms of government that very well may be alternated whenever the diversity is polarized. One might speculate that stable and success democracies are based on violence and non-participatory policies.

Rather, the liberal discourse, as in Huntington, shows many problems to understand the historical view of what is the politics, even democracy. This doctrine precludes that terrorism is not derived from democracies, but from the totalitarian countries. This fallacy has serious problems to be empirically validated. Besides, the problems of democracy depend on the degree of economic development. The following points have been extracted from the reading of Huntington views and liberal tradition:

1) The third wave of democratization, the characterized the life in Latin America, resulted from the previous temporal experience of totalitarian cultures with democracy.

2) Democracy and development should be the best instrument for a fairer redistribution of wealth.

3) It is important for US and Europe, functional to their securities, to expand democracy to emergent countries.

4) Failures in the adoption of democracy or development are product of cultural incompatibilities with rationalization such as the Islam and its own religious values that impede the democracy.

5) The future of Western will be circumscribed to an inevitable clash with East and its resentment. 
6) Pseudo-intellectuals are socialized in the belief the nation-hood is a value to be defended.

7) Finally, terrorism must be contemplated as a primary hazard to the style of life in West, a danger which should be eradicated.

Point by point, Huntington's argument not only alternates old-enrooted prejudices of Anglo-democrats, but also paves the ways to create a new form of cultural-imperialism. Anglo-democracy appeals to the intervention of those countries that do not accept its primary values of organization. Slavoj Zizek has already explained that sovereignty seems to be circumscribed to the manipulation of violence. The horror of violence backs on what is-no-said of that acting of violence. In this point, academician's thesis become in ideological discourses not necessarily for what they stress but for what they silenced. Ideology works as a dream, whereas the surface remains credible the core is false. The notion of false urgency is coined in observance of the last natural and made-man disaster ranging from the current Haiti's earthquake or Katrina's hurricane in US. Whenever these type of tragic events whip to poorer sector of the society, people donate their own properties in assistance of victims or survivors. It is not surprising to see a considerable volume of aid and money is bestowed to peripheral countries in moment of human emergency. Nonetheless, far-away of reversing the miserable conditions these countries stand, these types of assistance campaigns are often aimed at reinforcing the financial dependence.

From this perspective, Zizek distinguishes two sort of violence, objective and subjective. The former refers to the violence exerted by the system by means of ideology, police and State whereas the latter denotes the possibility to indentify and demonize to whom we consider the source of violence. For example, in America Islamic terrorists are deemed as the responsible of 9/11 attacks (subjective violence), this is the violence they feel in their kin. Secondly, objective violence seems to be invisible because it stems from the intervention of US in Middle East issues. For Zizek, subjective and objective violence are inextricably intertwined. For that reasons, scholars who denounce the violence received by Middle East (enrooted in cultural differences or clash or civilizations not only are completely wrong, they are exerting objective violence). The modern ethics is blurring the boundaries between victims and culprits (Zizek, 2009).

Following this, R. Bernstein (2006) argues that Democracy is more than a ritual accomplished every four years but a style of life. Existent Power does not surface as a pathway towards voluntary domination epitomized in a vertical upper position; it refers to necessary abilities human beings should develop for transforming jointly their own environment. This seems to be the paradox of totalitarianism which in the name of fraternization carries the destruction of alternative emerging voices. For this instance, Bernstein clarifies that George W. Bush's administration not only looked for expanding a spirit of freedom and democracy -in Iraq and Afghanistan- by means of military interventions but also is wholly convinced that God supports such a crusade. Of course, the belief of main American officials that "they are on the correct side" appears to be unquestionable whether we dwell on the rhetoric of recent policies against Iraq, 
Iran and North Korea (Bernstein, 2006). This begs a more than interesting question, ¿is terrorism a challenge for Anglo-democracy?.

It is truth Huntington sees the third world in connection with barbarity. West has accelerated its technological advance creating a wall respecting to the rest of the world. If one characterizes the civilization because of its monopoly of technology, the periphery is based on backwardness. The democrat order is employed as a sign of distinction in view of the following moto, the wealth of countries are explained by their attachment to liberty. If there are some states which are pours, this means that they are culturally incompatible with the ideal of civilization. This old prejudice not only has passed from one generation to another inside the liberal tradition, but also invaded the political science as well. The idealized form of democracy, developed in US, Hertz (2001) and Klein (2002) add, is insufficient to explain the material asymmetries in US nor justifying how elites pay for the candidate of politicians. Financing elections as the primary goal of elites is one subtle but powerful tactic to keep the control of the production mechanisms. In view of this, Sobhan alerts on the counter effects of the praised globalization in periphery. Its effects on the governance of agricultural based economies not only should be studied, but also denounced. Dictatorship does not surface unless by the intervention of democratic countries. The asymmetries provoked by the acceleration of trade engender serious problems in the legitimacy of under-developed states. The tenets of democracy are eroded by the process of globalization. What Huntington and liberal academicians forget is that "this erosion in state legitimacy has, in turn, compromised the quality of governance in particular countries and weakened their capacity to implement reform process. The extent to which freedom of action is compromised naturally depends on the economic structures of a country as well as the strength of its democratic institutions and capacity of effective governments" (Sobhan, 2003: 5).

The fact that a country develops a democratic or totalitarian form of government does not depend on culture. Democracy is not declining because of authoritarian drives inherited on cultural values but also by the expansion of a market which is amoral, impersonal and cold to humankind necessities. Huntington replies to this, that the problems of totalitarian governments are the lack of support to education associated to unskilled workforce needed to enable the production system. E. Said reminds that Huntington criticize the theory of clash of civilization simply because his aprioristic categorization does not rest on scientific foundations (Said, 2001)

M. Korstanje acknowledges that Anglo-nations and Latin Americans have persisted in different pattern to live the politics. This does not mean that one archetype is more or less democratic than the other. Both have focused on diverse topics of democracies. While Anglo-Saxon cultures developed a democracy based on their attachment to stable institutions, Latin American countries prefers to develop a goal-oriented sense of democracy. Unlike Us or England, South American nations appreciate democracy only if she may solve their daily problems, no matter than the ideology or party-related apparatus. This suggests that in these contexts, the pluralism of voices, parties and alternatives are larger than in Anglo-democracy. Although Americans 
disapprove the government of $G$. Bush, they put trust in the fact that their institutions will correct the problem. Rather, in Argentina or Colombia, the emphasis is given to ad-hoc alliance or the personal characteristics of some leaders (Korstanje, 2007).

With this background in mind, T. Veremis coincides with previous scholars that the Huntington's, account seems to be weak and generalized in the simplification of certain facts projecting mythical prophecies about a final conflagration between the forces of West and East. Even, what he considers the Islam compounds by a set of different ethnicities in historical disputes with their neighbors for long time. It is surprising to scare for a next clash of civilization whenever the First and Second Wars in Europe caused more than 100 million dead. Following this, Veremis clarifies that Huntington is mistaken in arguing we are experiencing a conflict of inter-civilization, this conflict is intracivilisational. Starting from the erroneous premise, Western civilization is based on values such as individualism, liberalism, human rights, liberty, equality, democracy, secularization and free markets, the others should be placed in opposition adopting a paranoiac mentality of West vs. East (Veremis, 2009).

Following Lafont's argument regarding the deliberative democracy, it almost impossible or at least utopian to figure out a global democracy wherein the selfdetermination of lay people with democratic control converges. This means no other thing than at the time democracy organizes other countries and of course the style of life of the new citizens more control and pressure is needed. Starting from the premise that democracy is often characterized by aspirations to freedom, it is paradox to see its own expansion suggests the idea of exerting more violence. For that reason, expansion of democracy is so authoritarian so those regimes this form of government is geared to fight. Other troubling point of entry seems to be the contrast between global and local perspectives in the formation of democratic regimes. Whether one may argue that democracy encourages the self-determination of citizens in participating into political decision-making and public sphere, this belief paves the ways towards the creation of local forms of government. Otherwise, if we are prone to create a global government encompassing the different local forms of organizations such individual self-determination should be diminished. Anyway, if this happens we will be witnessing the advent of a totalitarian regime. That way, the paradox of binary association democracy/authoritarianism is often misplaced into the interpretation of law. This idea ushers to a much broader dissociation between the figure of State and Democracy (Lafont, 2010).

\section{The intervention of democracy}

As noted in earlier sections, some left-wing scholars denounced that democracies reserve their own right to intervene other autonomous nations, simply because they keep a different form of organization. Paradoxically in this act, the Anglo-democracy becomes in a dictatorship. Although the right of intervening countries has been legalized by two figures, ius ad bellum and ius in bellum, the ways and procedures to declare and conduct an attack arguing humanitarian issues (Bellamy, 2009), the fact is that this ethical problem 
remains unresolved. What would opine Huntington to the pervasive role played by US in mitigating the effects of terrorism in Colombia?

The problem of terrorism not only dichotomized the public opinion in two, but also opened the door for initiating a hot-debate respecting to the role played by United States as protector or instigator of conflict in Colombia. In his book, Violencia Publica en Colombia 1958-2010 (Public Violence in Colombia 19582010 M Palacios emphasizes on the role played by Columbian elites to protect their interest in lieu of promoting the collective well being. Since its inception, the economy was based on colonial latifundium. The rivalry between capital land-owners and peasants was determined by their access to land. Nor militaryforces neither the police were intervening in hinterlands as other Latin American countries. Colombia is unique in its genesis and consequent evolution. As a result of this, the social conflict became in a mediator so that peasant may resolve their disputes. The lack of state in these places was conducive to the decision of elite to gain further legitimacy in the main towns. The gravamen of financial taxes generated an ongoing state of emergency that resulted in a climate of resentment and exclusion. Serious problems in the administration of the finances created serious material asymmetries in the country.

The context in the main cities was not different. In order for elite not to loose the control, before the incipient discontent of worker-unions, violence of terrorism was manipulated as an instrument of discipline and control upon the work-force. Unlike other neighboring countries where army-forces were disposed to conduct coups against the civilians, in Colombia was the government the body that employed the problem of terrorism in its own favor. In political terms, the sense of hobessian Leviathan that exhibits the legitimacy of state as an allencompassing institution which monopolizes the use of violence is not completed in Colombia. The legal and illegal circuits raised the consciousness of aristocracy at time of dissuading worker-union to continue their claims. While, at the surface a cynic aristocracy protected their businesses by means of the democracy and the respect of law, on another, the human rights of poorer peasants were systematically violated once and once again. Terrorism was only a pretext to introduce policies which otherwise would be rejected by the society.

By the way, two events were of capital importance to deepen the conflict between the Government and its hinterland. One of them signals to Castro's revolution and the effects to other developing countries, which ranged from 1970 to 1980 . Secondly, the introduction of Drug-traffic in Rural zones to give financial resources to the Guerrilla, whose epicenter started from 90 s decade on.

As explained above, the conflict between cities and hinterland was accelerated but not determined after the Castro revolution in Cuba and by the Cold War. If the state and aristocrats adopted the suggestions of the United States as guidelines to regulate internal conflict, insurgents were inspired by Cuba to carry on their anti-establishment activities. A correct understanding of the situation reminds that terrorists (guerrillas) have been implanted in those zones where authority of government was weakest. If anomie inflicted by the government was conducive temporarily to its interests, now it becomes in a big 
problem. Based on a romantic discourse, Castro inspired the rebels of many countries in Latin America not only against US, but alto to Soviet bloc. In Colombia, peasants adopted the model of Cuba but at the same time, reproduced the old stereotypes of rivalry between the center and its periphery. The populist voice initiated by "gaitanismo" was now silenced by the cold-war. Palacios said that Colombia failed to forge a national-consciousness according to its own needs and history. Palacios calls the attention of liberal scholars who preclude the role of US in promoting terrorism depending on the contextual interests.

To understand this, C. Tomlins (1990) explains, US from its inception was based on a ideological dichotomy, republicanism and liberalism. The former stressed the primacy of politics to ensure the social order and happiness while the latter one turned its attention to the role of markets in coalescing rights and consumption. Any constitutional nature, would promote the equality so that all may pursue a communal order, while the liberals were historically more concerned to protect the one's self-interests. The law and the code as have been typified were oriented to protect the rights of elites. The politics were subordinated to the logic of market. This dichotomy was resolved in favor of liberal discourse, though Tomlins adds, the Republic persists. B. Bailyn noted that US combined two contrasting tendencies, inherited from British Empire, freedom with imperialism. United Kingdom colonized the new world by the combination of freedom in their primary cities, and a cruel violence exerted on the colonies where the corruption avoided the collective fragmentation. The British monarchy preferred to enhance the wealth in opposition to local American resentment. The liberty was applied to grant the nature of man, while the violence paved the ways for the advent of independence. The idea of democracy and empire, from this moment onwards, coexisted in the history of America (Bailyn, 1965).

Hardt \& Negri admits that any imperial system is configured to corrupt the peripheries. The revolts and discontents are neutralized by the introduction of politic corruption. In this process the trade is of paramount importance because connects systems with smaller subsystems. To globalize the capital by dint of the credit, US appealed to a biased sense of democracy and human rights. Both concepts not only give to this country the privilege to expand their hegemony to peripheral zones but also make us to believe this is the best organization we can dream. Whenever some groups threaten the capital order, the army machinery is moved to grant the stability of empire. Following this argument, we have to conclude, democracy, corruption and capital seems to be conducive to the production of a new Empire (Hardt \& Negri, 2002; Hardt \& Negri, 2004). The Anglo-Empire triggered by England is continued today by US. The same policies persist. Trade generates the liberalization of bonds so that the market can create the needs to fulfil. In this process, people are commoditized as consumable objects (Bauman, 2007). 


\section{Conclusion}

In the present paper we have explored the problems and dichotomies in the thought of Samuel P. Huntington. The points discussed here do not exhibit a radical criticism to him, but to the ideological view he represents, this means the liberal view of some American liberals. Not only the concept of radical clash of civilization rests on shaky foundations, but also the development of what is a democratic country needs further review. Huntington portrays an ethnocentric discourse, conducive to the geopolitics interest of US in the world that combines an historical myopia to understand the politics with the idea that Unites States represents the more sublime values of democracy. At some extent, his definition of the problems of terrorism leads to misjudge the connection between terrorism and democracy. As James Piazza put it, historically the acts of terrorism emerged from the democracies, first whenever the elite prohibited the voice of some minorities. We have far away of finding a correct antidote against terrorism but likely a coherent diagnosis may be given if we pay heed to the historical roots of democracy and its deformation in the Anglo-democracy.

\section{Bibliography}

Almond, G. \& Verba, S. (1963). The Civic Culture. New Jersey, Princeton University Press.

Altheide, D. (2006). Terrorist and the Politics of Fear. Oxford, Altamira Press.

Altheide, D. (2009). "Moral Panic, From sociological concept to public discourse". Crime and Media Culture. Vol. 5 (1): 79-99.

Bailyn, B. (1965). The Origins of American Politics. New York, Vintage Book.

Bay, C. (1992). "Politics and Pseudo-politics: a critical evaluation of some behavioural literature". In Approaches to the Study of Politics, Bernard Susser (editor). New York, Macmillan Co. pp. 51-75

Baudrillard, J. (1995a). The systems of the objects. Mexico, Siglo XXI.

Baudrillard, J. (1995b) The Gulf War Did Not Take Place. Sydney, Power Publications

Baudrillard, J. (2006). "Virtuality and Events: the hell of power". Baudrillard Studies. Vol. 3 (2). July. Availabe at http://www.ubishops.ca/BaudrillardStudies/. Bishop's University, Canada. Version translated by Chris Turner.

Bauman, Z. (2007) Consuming life. Cambridge, Polity Press.

Bellamy, A (2009) Just Wars, from Cicero to Iraq. Buenos Aires, FCE.

Bernstein, R. (2006). The Abuse of Evil. The corruption of politics and religion since 9/11. Buenos Aires, Katz.

Birdsall, N. (2001). "Why Inequality matters. Some economic issues". Ethic \& International Affair. Vol. 15 (2): 3-28.

Birdsall, N. (2006). "Rising Inequality in the New Global Economy". International Journal of Development Issues. Vol. 5 (1): 1-9.

Castel, R. (1997). La Metamorfosis de la Cuestión social. Una Crónica del salariado. Buenos Aires, Paidos.

Castoriadis, C. (2006). What shapes Greece: from Homer to Heraclitus. Seminaires 1982-1983. Human Creation II. Buenos Aires, Fondo de Cultura Economica. 
Corey, R. (2009). Fear, the history of Political Ideas. Mexico, Fondo de Cultura Económica.

Dahl, R. A. (1992). "The Bahavioral Approach in political Science: Epitaph for a monument to a Succesfull Protest". In Approaches to the Study of Politics, Bernard Susser (editor). New York, Macmillan Co. pp. 27-48

Diamond, L. (2010). "Why are there no Arab Democracies?". Journal of Democracy. Vol. 21 (1): 92-104.

Easton, D. (1992). "Tenets of Post-Behaviouralism". In Approaches to the Study of Politics, Bernard Susser (editor). New York, Macmillan Co. pp. 49-50

Fukuyama, F. (1989). "The End of History". The national Interest. Vol. 16 Summer: 4-18.

Gray, C. S. (2007). "The Implications of Preemptive and Preventive war Doctrines: Reconsideration". Department of the Army, Department of Defense, US Government. Available at

http://www.strategicstudiesinstitute.army.mil/Pubs/display.cfm?pubid=789

Haggard, S \& Kaufman, R. (1995). The Political Economy of Democratic Transitions. New Jersey, Princeton University Press

Hardt, M \& Negri, A. (2002). Empire. Buenos Aires, Paidos.

Hardt, M \& Negri A.. (2004). Multitude. War and democracy in the age of Empire. Debate, Barcelona.

Heidegger, M. (1997). El Ser y el Tiempo. Santiago, Editorial Universitaria.

Hertz, N. (2001). The silent Takeover. Global Capitalism and Death of Democracy. London, William Heinemann

Holloway, J and Paláez, E. (2002). "La guerra de todos los estados contra toda la gente". En Guerra Infinita: hegemonía y terror mundial. Ceceña, A. y Sader, E. Buenos Aires, CLACSO. Pp. 159-166.

Howie, L. (2009). "A Role for Business in the War on Terror". Disaster Prevention and Management. Vol. 18 (2): 100-107.

Huntington, S. P. (1993). The Third Wave. Democratization in the Late Twentieth Century. Oklahoma, Oklahoma University Press.

Huntington, S. P. (1997). The Clash of Civilizations: Remaking of World Order. New York, Touchstone Book.

Keohane, N \& Zeckhauser, R. (2003). "The ecology of Terror defense". Journal of risk and Uncertainty. Vol. 26 (2-3): 201-229.

Klein, N. (2002). Fences and Windows: Dispatches from the front lines of the Globalization Debate. London, Hammersmith.

Kristol, W. \& Kagan, R. (1996). "Toward a Neo-Reaganite Foreign Policy". Foreign Affairs. July /August issue.

Kepel, G. (2002). "Los Hechos del 11 de Septiembre de 2001". En El Mundo Después del 11 de Septiembre de 2001. (Compilación). Barcelona, Editorial Península. Pp. 25-43.

Korstanje, M. (2007) "La Democracia y sus supuestos, una perspectiva comparativa entre los conceptos de democracia procedimiental y estructural". Estudios Sociales. Vol. 16 (30): 46-78

Lafont, C. (2010). "Can Democracy go global?". Ethics \& Global Politics. Vol. 3 (1): 13-19.

Lucero, J. A. (2001). "Crisis and Contention in Ecuador". Journal of Democracy. Vol. 12 (2).

Miles, R. (1999). Racism. New York, Routledge.

Murillo, S. (2008). Colonizar el Dolor. Buenos Aires, CLACSO. 
Palacios, M. Public Violence in Colombia. 1958-2010 (violencia pública en Colombia, 1958-2010). Bogotá, Fondo de Cultura Económica.

Pech, R. and Slade, W. B. (2006). "Religious Fundamentalism and Terrorism: why do they do it and what do they want?". Foresight. Vol. 8 (1): 8-20.

Piazza, J. (2008) Do democracy and free markets protect us from terrorism. International Politics, vol 45: 72-91

Pojman, L. (2006). Terrorism, Human Rights and the case for World Government. Lanham, Rowman and Littlefield.

Powell, J. (2010). "Neo-liberalism and Globalization: repetitious inequalities and the implication for a global social theory". Sincronia: a journal of Social Sciences and Humanities. Spring. University of Guadalajara, Mexico.

Rashid, A. (2002). "Los Hechos del 11 de Septiembre de 2001". En El Mundo Después del 11 de Septiembre de 2001. (Compilación). Barcelona, Editorial Península. Pp. 13-23.

Raventós, C. (2008) Democratic Innovation in the South. Participation and Representation in Asia, Africa \& Latin America. Buenos Aires, CLACSO Books Rawls, J. (1999) The Law of Peoples Cambridge, Harvard University Press. Said, E. (2001). "The Clash of Ignorance". The Nation. October 4. Available at http://www.thenation.com/article/clash-ignorance.

Skoll, G. (2007). "Meaning of Terrorism". International Journal for The Semiotics of Law. Vol. 20: 107-127.

Smaw, E. (2008). "From Chaos to Contrarianism: Hobbes, Pojman, and the Case of World Government". Essays in Philosophy. Vol. 9 (2): 4-18. Available at www.commons. pacificu.edu/eip.

Sobhan, R. (2003). "Globalization and the Challenge to democracy". International Journal of Development Issues. Vol. 2 (2): 1-14.

Sontag, S. (2002). "Seamos Realistas". En El Mundo Después del 11 de Septiembre de 2001. (Compilación). Barcelona, Editorial Península. Pp. 59-61.

Susstein, C. (2005). Laws of Fear: beyond the precautionary Principle. Cambridge, Cambridge University Press.

Susser, B. (1992). "The Behavioural Ideology: a review and a retrospect". In Approaches to the Study of Politics, Bernard Susser (editor). New York, Macmillan Co. Pp. 76-97

Tomlins, C. (1990). "Law, police and the persuit of happiness in the New American Republic". Studies in American Political Development, Vol 4, Pp 3-34. Yale University Press.

Vargas Llosa, M. (2002). "La Lucha Final". En El Mundo Después del 11 de Septiembre de 2001. (Compilación). Barcelona, Editorial Península. Pp. 53-58. Veremis, T. (2009). "Clash of Civilizations or International Dialogue?. Obituary of Samuel P. Huntington (18 April 1927 - 24 December 2008). The Historial Review. Volume VI: 243-249

Wolin, R. (2010). "The idea of cosmopolitanism: from Kant to the Iraq war and beyond". Ethics \& Global Politics. Vol. 3 (2): 143-153.

Zizek, S. (2009). Violence. Buenos Aired, Paidos. 